\title{
Customer Retention Strategies For Disintermediated Travel Agents: How To Stop Customers From Migrating To Online Booking Channels
}

K. Viljoen, University of Johannesburg, South Africa

M. Roberts-Lombard, University of Johannesburg, South Africa

\begin{abstract}
$*$
Remaining relevant to customers and retaining customers who could consider booking online, requires travel agents to modify their marketing strategies. Travel agents need to find new ways to add value for customers and suppliers to reinstate their roles in the travel distribution process and ultimately retain their customers. A total of 600 travel agencies in South Africa participated in the study through the completion of an online survey. The data analysis technique used for the study was path analysis. The findings stipulate that travel agency owners and managers believe that providing differentiated products to their leisure customers, is the key to winning back lost customers and keeping existing customers. Travel agency owners and managers further indicated that this is an existing reintermediation strategy that they plan to practise in the future as well. It is therefore recommended that travel agents focus on delivering high-quality service to win back lost customers and thus reintermediate their businesses.
\end{abstract}

Keywords: Disintermediation; Reintermediation; Customer Retention; Marketing Strategies; Travel Agents

\section{INTRODUCTION}

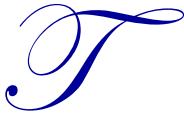

he global travel industry has been at varied stages of transition over the last decade. The travel industry operates in a competitive, volatile environment that is shaped by external forces (Lubbe, Endres, \& Ferriera, 2006:35 and Wolfe, Kang, \& Hsu, 2005:73). The volatility of this environment has developed due to high levels of technological advancement, declining economic conditions, increasing threats of terrorism and fierce competition in general (European Travel Commission, 2012:27; Garkavenko, 2007:140 and World Travel Market, 2010:25).

The travel and tourism industry is regarded as highly significant in the global economy as it is considered the world's leading employer (Kruger-Cloete, 2007:17). Travel agencies are a critical component of this industry as they bridge the gap between buyer and seller. However, with technology advancing as rapidly as it is, the Internet has facilitated a definite movement towards direct distribution and thus direct travel bookings (Dolnicar \& Laesser, 2007:134 and Wolfe, et al., 2005:74). Nearly half of all travel bookings globally are currently made online while travel agents conclude only a third of the world's travel bookings. The migration to online bookings is evidenced by the decline of air ticket sales recorded by travel agents (World Travel Trends Report 2011/2012; Shaw, 2007:214 and Wardall, 2006b:24).

Along with this technological change, the modern customer has also evolved. Time is of the essence and the Internet has created a demand for instantaneous transactions and instant gratification (Salvado, Ferreira, \&

\footnotetext{
* This paper has been published in the March/April 2016 issue of the Journal of Applied Business Research, 32(2), 541-554. However, the paper was withdrawn on the request of the authors and modified to secure reference to the first part of the study that was published in the International Business Review, 14(3), 561-574. The publication of this paper in the May/June issue of the Journal of Applied Business Research reflects on the second part of the study.
} 
Costa, 2011:231). Traditional travel agencies have to redefine their roles as intermediaries by adding value in an alternative manner to still be included in the travel distribution process (Gaynor, 2006:11; Gerber, 2006:11 and Rutter, 2006:10). Remaining relevant to customers and retaining customers, who could easily opt to book online, requires travel agents to modify their marketing strategies.

\section{LITERATURE REVIEW}

\section{The Evolution from a Disintermediation Approach Towards Reintermediation}

Historically, it has been geographically impossible for suppliers to interact directly with their customers hence the need for the intermediation function in a business. However, the basic intermediation functions of information provision, logistics and risk taking have become devoid due to the advent of the Internet. This has resulted in shorter distribution channels as redundant intermediaries are removed. The basic rationalisation for this is suppliers attempting to cut costs (Hanson \& Kalyanam, 2007:146 and Kracht \& Wang, 2009:744). These modifications in the intermediation process have resulted in the occurrence of disintermediation. Disintermediation therefore refers to customers dealing directly with manufacturers/suppliers and bypassing traditional channel members (Ferrell \& Hartline, 2008:275).

Disintermediation has displaced many intermediaries who have had to find new ways to position themselves in the market, hence the introduction of reintermediation (Huang, Chen, \& $\mathrm{Wu}$, 2009:737). Reintermediation involves previously disintermediated middlemen offering a new value proposition to become part of the distribution channel again (Shunk, Carter, Hovis, \& Talwar, 2007:249). This new value proposition often includes Internet activities (Cant, Strydom, Jooste, \& Du Plessis, 2006:507). Therefore, travel agents who were a critical intermediary in the travel distribution process are now perceived as another costly intermedial layer by customers and suppliers alike. Travel agents need to find new ways to add value for customers and suppliers to reinstate their roles in the travel distribution process, and thus reintermediate their businesses. Through reintermediation, travel agents will be able to retain customers in the long term (Andreu, Aldas, Bigne, \& Mattila, 2010:777).

\section{Reintermediation Factors Leading to Customer Retention}

Five potential reintermediation factors influencing customer retention have been identified in literature (ABTA, 2012:4; Grissemann \& Stokburger-Sauer, 2012:1483; Cheung, 2012:8 and Huang, Yung \& Yang, 2011:142). These factors have been adopted from a study conducted by Viljoen (2015) which focused on eight reintermediation factors. The focus of this article is differentiated in that it relates to customer retention as opposed to reintermediation. However, it is essential to acknowledge the original study and cite the resulting hypotheses proposed in that study hence the variables repeatedly centre on reintermediation (as per the original study) and customer retention (for the purposes of this analyses and resultant article).

Following the literature on the five proposed factors, is a discussion on customer retention and its importance to travel agencies. The first potential reintermediation and customer retention factor discussed is that of product knowledge.

\section{Product Knowledge}

As cited in Viljoen (2015:565) various studies have focused on the importance of service providers' knowledgeability and the influence (Spake \& Megehee, 2010; Trivedi, Morgan, \& Desai, 2008; Verbeke, Dietz, \& Verwaal, 2010). Verbeke et al. (2010:17) emphasise that the absorptive learning ability of sales persons and their related cognitive aptitude are paramount in being able to sell products or services to customers. This should result in travel agents using their extensive product knowledge to retain customers. The resultant hypotheses are $1 \mathrm{a}$, as per the original study, and $1 \mathrm{~b}$ for the purpose of this article:

Ho(1a): A significant relationship between travel agents' product knowledge and reintermediation is not evident in travel agencies. 
H1a: A significant relationship between travel agents' product knowledge and reintermediation is evident in travel agencies.

Ho(1b): A significant relationship between travel agents' product knowledge and customer retention is not evident in travel agencies.

H1b: A significant relationship between travel agents' product knowledge and customer retention is evident in travel agencies.

\section{Personal Interaction}

Due to the abundance of choice that consumers are presented with, the aspect of developing consumer intimacy has come under scrutiny as a potential solution to create long lasting connections with customers (Bove \& Johnson, 2009:188). As indicated in Viljoen (2015:566) literature advocates face-to-face interaction between service personnel and customers being the key to building and reinforcing customer relationships (Lloyd \& Luk, 2011; Ple \& Caceres, 2010; Spielman \& Babin, 2011). It is believed that travel agents facing a reintermediation process need to enhance human interaction and consumer trust in order to retain customers and attract new customers (Grissemann \& Stokburger- Sauer, 2012:1483; Kracht \& Wang, 2009:747). This leads to hypotheses $2 \mathrm{a}$, as per the original study, and $2 \mathrm{~b}$ for the purpose of this article:

Ho(2a): A significant relationship between travel agents' ability to interact personally with customers and reintermediation is not evident in travel agencies.

H2aA: significant relationship between travel agents' ability to interact personally with customers and reintermediation is evident in travel agencies.

H0(2b): A significant relationship between travel agents' ability to interact personally with customers and customer retention is not evident in travel agencies.

H2bA: significant relationship between travel agents' ability to interact personally with customers and customer retention is evident in travel agencies.

\section{Differentiated Product}

Differentiated products and services attract the most customers across industries and the travel industry is no different. Researchers agree that travel agencies need to focus on the development of unique travel packages in order to attract and retain customers (Cheung, 2012:8; Kracht \& Wang, 2009:751; Ku, Yang, \& Huang, 2012:17). Some examples of differentiated products targeting niche market segments include agencies that only sell island holidays, golfing or bird-watching packages (Turen, 2008:2). This results in hypotheses $3 \mathrm{a}$, as per the original study, and $3 \mathrm{~b}$ for the purpose of this article:

H0(3a): A significant relationship between travel agents offering a differentiated product to customers and reintermediation is not evident in travel agencies.

H3a: A significant relationship between travel agents offering a differentiated product to customers and reintermediation is evident in travel agencies.

H0(3b): A significant relationship between travel agents offering a differentiated product to customers and customer retention is not evident in travel agencies.

H3b: A significant relationship between travel agents offering a differentiated product to customers and customer retention is evident in travel agencies. 


\section{High-Quality Service}

It is believed that high-quality service is an essential criteria that consumers use in selecting a travel agency (Wolfe, et al., 2005:73). Frost, Nordlof, \& Svesson (2009:62) support this statement and cite high-quality service as an essential ingredient to retaining customers. This leads to hypotheses $4 \mathrm{a}$, as per the original study, and $4 \mathrm{~b}$ for the purpose of this article:

H0(4a): A significant relationship between the provision of high-quality service by travel agents and reintermediation is not evident in travel agencies.

H4a: A significant relationship between the provision of high-quality service by travel agents and reintermediation is evident in travel agencies.

H0(4b): A significant relationship between the provision of high-quality service by travel agents and customer retention is not evident in travel agencies.

H4b: A significant relationship between the provision of high-quality service by travel agents and customer retention is evident in travel agencies.

\section{Co-Existing with Technology}

Salvado, et al. (2011:242) and Wang, Gal-Or, and Chatterjee (2009:968) advocate that for travel agencies to remain relevant in this technology driven era, they need to adopt adequate technological systems to service customers. Garkavenko (2007:143) indicates that travel agents have no alternative and cannot afford not to embrace the Internet as a travel supplier. This ushers in hypotheses $5 \mathrm{a}$, as per the original study, and $5 \mathrm{~b}$ for the purpose of this article:

H0(5a): A significant relationship between travel agents who co-exist with technology and reintermediation is not evident in travel agencies.

H5a: A significant relationship between travel agents who co-exist with technology and reintermediation is evident in travel agencies.

H0(5b): A significant relationship between travel agents who co-exist with technology and customer retention is not evident in travel agencies.

H5b: A significant relationship between travel agents who co-exist with technology and customer retention is evident in travel agencies.

\section{Customer Retention and Reintermediation}

Prior research has established that customers are one of the most important assets that a business possesses (Schulze, Skiera, \& Wiesel, 2012:17). Many businesses focus on trying to attract new customers as opposed to retaining existing customers (George, 2008:457 and Ting, 2012:4551). Business researchers have been investigating the concept of how to retain existing customers for decades (Gustafsson, Johnson, \& Roos, 2005:210; Nitzan \& Libai, 2011:24; Reinertz, and Voss \& Voss, 2008:6). Customer retention can be defined as 'the number of customers doing business with a firm at the end of the financial year, expressed as a percentage of active customers at the beginning of the year' (Buttle, 2009:258). Effectively, customer retention means customers continue to support businesses and thus demonstrate repeat patronage (Trassorras, Weinstein, \& Abratt, 2009:628).

Customer retention is of particular importance to business managers and marketers as it allows for the calculation of a customer's lifetime value and this impact the profitability of the business (Nitzan \& Libai, 2011:24). A five percent increase in customer retention can increase profits by up to 75 percent (Trassorras, et al., 2009:620). 
George (2008:457) and Ting (2012:4551) believe that retaining customers in the tourism industry is particularly difficult, because it is easy for customers to switch between suppliers. Ahmad and Buttle (2002:151) argue that customers will only stay if a good value proposition is made to them. Trassorras, et al. (2009:615) concur and cite the delivery of value and keeping customers as key concerns in highly competitive markets, such as the travel industry. These authors suggest that businesses should focus on customer value and retention to increase or improve overall profitability (Trassorras, et al., 2009:615). They implicitly state that customer retention is impossible without creating superior value for customers first (Trassorras, et al., 2009:628). In the context of this study, this proposes that travel agents should offer their customers additional value in some form. It is through this additional value offered that travel agents will ultimately retain customers.

Reintermediation has evolved from a systematic cycle of intermediation, disintermediation, reintermediation and most recently, cybermediation. Through reintermediation, previously disintermediated middlemen now offer a new value proposition in order to become part of the distribution channel again (Shunk, et al., 2007:249). With this in mind, the relationship between reintermediation and customer retention for the purpose of this article can be hypothesised as:

H0(6): A significant relationship between reintermediation and the retention of customers is not evident in travel agencies.

H6: A significant relationship between reintermediation and the retention of customers is evident in travel agencies.

Figure 1 depicts the six hypotheses and thus the proposed reintermediation /customer retention model. Ultimately, a link is proposed between each reintermediation factor individually and in turn, reintermediation linking to customer retention. Alternatively, factors could directly influence customer retention and have no bearing on reintermediation.

Figure 1. Proposed theoretical reintermediation/customer retention model

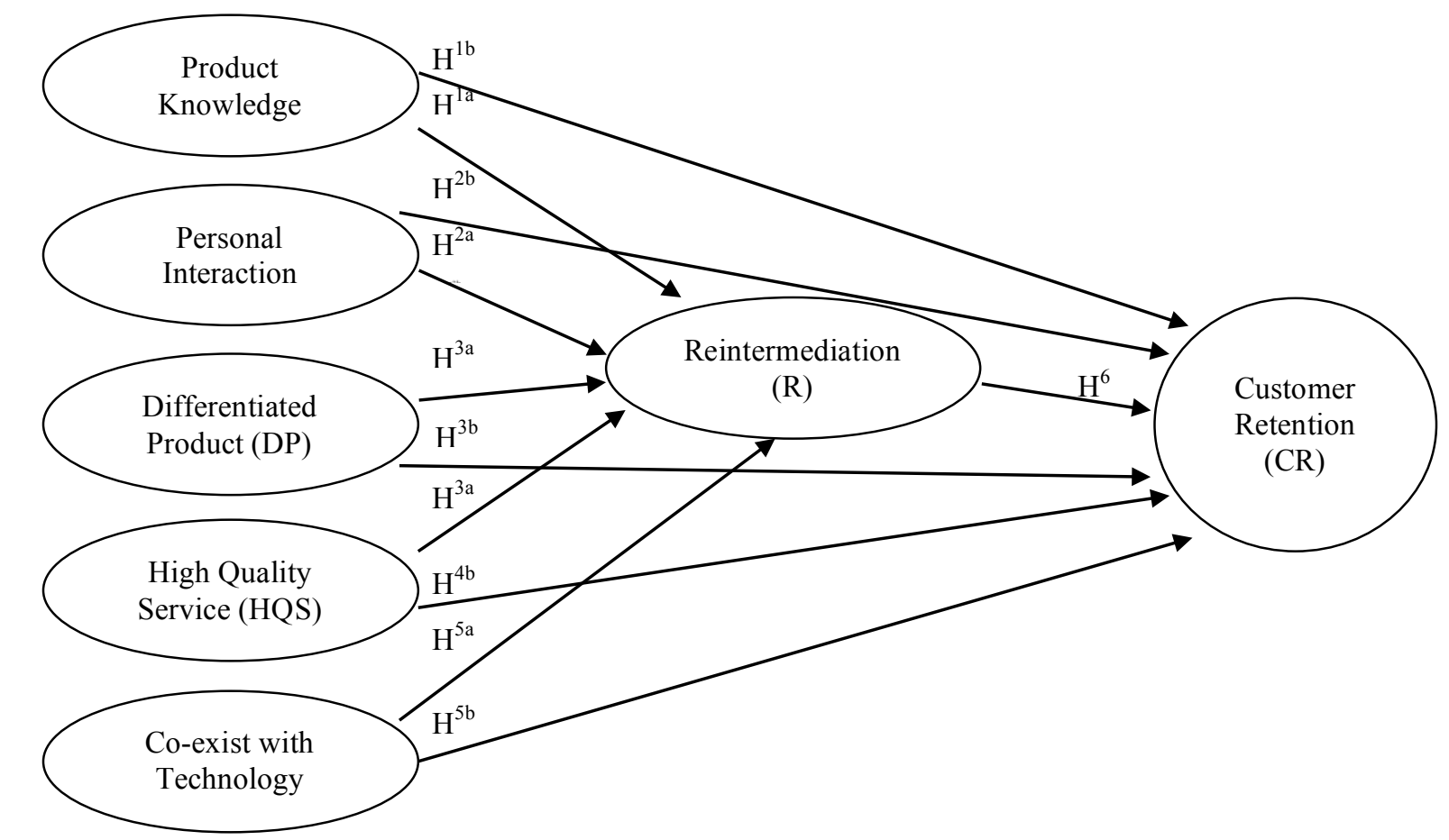

Source: Developed for this study 


\section{PROBLEM INVESTIGATED}

As was cited in Viljoen (2015:567) traditional intermediaries are being faced with turbulent economic conditions in the marketplace and urgent adaption of marketing and business practices is required. Disintermediation has occurred in the travel industry and continues to alter the structure of travel distribution channels (Kracht \& Wang, 2009:739). Travel agents have been disintermediated and, therefore, have to change the way in which their businesses are managed and marketed to combat this threat. Research to date has not provided compelling evidence and guidelines for travel agents to follow to reintermediate their businesses and to retain customers. The research question therefore is what specific factors can be regarded as reintermediation and/or customer retention factors for travel agents, which will result in their long- term profitability. The literature on the travel industry and extant literature on the services industry postulate that the five factors could serve as reintermediation and/or customer retention strategies. This article specifically explores the relationship between these proposed factors and reintermediation or customer retention, with a specific focus on strategies to retain customers. The research objectives are set out in the following section.

\section{Research Objectives}

Emanating from the research problem and the previous study on this topic, the research objectives for this study were as follows:

- To determine whether the Reintermediation or customer retention factors derived from the theoretical basis have a perceived influence on Reintermediation in travel agencies.

- To establish which of the identified Reintermediation or customer retention factors have the largest influence on Reintermediation and thus on customer retention in travel agencies.

- To ascertain which factors have the largest perceived impact on Reintermediation or customer retention in travel agencies.

- To make recommendations to the travel agency industry on their Reintermediation strategies to enhance customer retention in the industry.

\section{RESEARCH METHODOLOGY}

The study was quantitative and exploratory in nature and incorporated an electronically administered survey that was distributed to 600 travel agency owners and managers in SA. The population included all the travel agents registered with the Association of South African Travel Agents (ASATA) in South Africa, as well as travel agents listed in the electronic yellow pages. The target population for this study was therefore approximately 1300 travel agencies in South Africa of which 600 were requested to participate in the completion of the questionnaire. Ultimately, a response rate of $25 \%$ was obtained for this study $(n=150)$.

There were a variety of scales from an assortment of credible sources which were adapted to measure the specified variables (Chau \& Hu, 2001:707; Feltham 1994, cited in O'Bearden \& Netermeyer, 1999:290; Lichtenstein, Ridgway, \& Netemeyer 1993, cited in O'Bearden \& Netermeyer, 1999:273; Lynn \& Harris 1997, cited in O’Bearden \& Netermeyer, 1999:101; Parasuraman, Zeithaml, \& Berry, 1998:39 and Reinartz, et al., 2004:303). A mixed methodology design process was implemented, which incorporated a pilot study with associated modifications to the questionnaire to ensure reliability and validity of the research instrument. Ultimately, a five-page questionnaire containing three sections was developed for the study. The first section was an introduction to the study and the second section contained questions related to management biographical data and business demographical data. A ranking question relating to the reintermediation/customer retention factors was located in the second section of the questionnaire. The third section comprised of 58 five-point double-sided Likert scales relating to the constructs being tested.

As per the analytical techniques used in Viljoen (2015), the data analysis strategy used for the survey incorporated descriptive and inferential statistical techniques. The core components of the inferential analysis consisted of exploratory and confirmatory factor analyses, structural equation modelling (SEM), correlation analysis, linear and mediation regression and lastly, path analysis. The difference between path 
analysis and structural equation modelling is that path analysis analyses relationships between variables at construct level, as opposed to structural equation modelling that deals with relationships at an item level. The use of path analysis was used in the original study as well as this study as path analysis modelling produced better-fit statistics for both models and ensured higher correlation coefficients than SEM. Path analysis also allowed for the inclusion of more reintermediation variables in the models than SEM did. The following section outlines the findings.

\section{DISCUSSION OF RESULTS}

\section{Reliability and Validity}

The reliability and validity statistics of the model constructs can be reported as the same as those achieved in Viljoen (2015:570). To reiterate the findings, the scales were regarded as reliable as the Cronbach's alphas ranged between .638 and .896 . With respect to the exploratory factor analysis, three factors, namely product knowledge, personal interaction and co-existing with technology, proved to be uni-dimensional and the respective scale items remained unchanged. The factor loadings for the product knowledge items ranged from between .571 to .839 , while the factor loadings for the personal interaction items ranged from .683 to .833 and the co-existing with technology items exhibit factor loadings that ranged from .481 to .865 .

Factor loadings during the exploratory factor analysis regarding reintermediation, differentiated product, highquality service and customer retention revealed that the validity of the respective scales proved to be problematic, thus the scales required adjustments. After these modifications had taken place, a confirmatory factor analysis was conducted. Results indicated that high-quality service and customer retention were each retained as single measures. Two factors, namely reintermediation and differentiated product split into separate sub-factors, indicating non-unidimensionality and resulting in the development of four measures. The reintermediation factor loadings across items in both measures spanned .704 to .825 . With respect to the reintermediation construct splitting into two factors, the study that informed this article (Viljoen, 2015) viewed reintermediation and validated reintermediation, as having a dual meaning. Reintermediation can either be regarded as winning back lost customers that have been lost due to disintermediation (R1) or as adapting business processes used to retain customers (R2).

Furthermore, it can be noted that the differentiated product has also been split into two, namely a differentiated product factor specifically for corporate customers, and a differentiated product factor for leisure customers. With respect to the differentiated product corporate items factor loadings, items ranged from .398 to .827 , while the differentiated product leisure items ranged from .489 to .805 . The modified scales were re-tested for reliability and all displayed Cronbach's alpha scores of over .600. Table 1 provides an overview of the final Cronbach's alpha values for the different scale items.

Table 1. Reliability Statistics

\begin{tabular}{l|c}
\hline \multicolumn{1}{c}{ Scale (Items) } & Cronbach's Alphas \\
\hline Reintermediation (9) & .870 \\
\hline High-quality service (11) & .876 \\
\hline Differentiated product (6) & .705 \\
\hline Product knowledge (5) & .791 \\
\hline Personal interaction (5) & .896 \\
\hline Co-existing with technology (5) & .827 \\
\hline Customer retention (6) & .780 \\
\hline
\end{tabular}

Table 2 proceeds with confirming construct validity with an indication of factor loadings per statement in each construct. 
Table 2. Confirmatory Factor Analysis Results

Factors and Statements

Factor loading

Reintermediation 1

B26 Our travel agency has developed a system for interacting with inactive customers.

B12 Our travel agency has a systematic process/approach to re-establish relationships with valuable

customers whom we have lost.

B61 Our travel agency has a systematic process for re-establishing relationships with valued inactive

.825

customers.

B7 Our travel agency has a system in place to be able to interact with customers who are no longer using

.809 our service.

Reintermediation 2

B53 Our travel agents have modified their operations to compete effectively with customers making

travel arrangements independently on the Internet.

B63 Our travel agency has developed new strategies to attract new customers who currently make

independent bookings online.

B56 The ability of customers to make their own travel arrangements on the Internet has forced our agents

to offer customers additional value (in some form).

\section{High-quality service}

B9 Customers feel safe in their transactions with our travel agents.

B10 Our travel agents are polite.

B8 Management at our travel agency trusts its employees.

B23 Our travel agents are sympathetic and reassuring towards customers and their problems.

B24 Our travel agents are reliable.

B5 Our travel agents keep accurate records.

B32 Our travel agency employees are well-dressed and appear neat.

B60 When our travel agents promise to do something by a certain time, they do so.

B52 Our travel agents deliver prompt service to customers.

Differentiated product 1

B31 The majority of our corporate customers like to try new travel products and services.

.704

.730

.426

B16 The majority of our corporate customers enjoy buying travel products that are different and unusual.

B25 The majority of our corporate customers often want customised features for their travel products and services.

Differentiated product 2

B29 The majority of our leisure customers prefer custom-made travel packages as opposed to ready-made travel packages.

B2 The majority of our leisure customers prefer to travel to unique travel destinations.

B62 The majority of our leisure customers are attracted to different travel products and services.

Product knowledge

B46 Our travel agents are informative.

B28 Our travel agents provide innovative solutions.

B11 Our travel agents are knowledgeable.

B34 Our travel agents are rational.

B58 Our travel agents are credible.

Personal interaction

B15 Our travel agents stimulate customers emotionally about their travel plans.

B27 Our travel agents emotionally move customers who plan to travel.

B4 Our travel agents stir the emotions of their customers.

B1 Our travel agents excite customers about their travel plans.

B30 Our travel agents reach out to customers emotionally.

Co-exist with technology

B14 Using technology fits with our travel agency's business needs.

B13 Our travel agents find technology easy to use.

B35 Using technology fits in with the way our travel agents work.

B6 Our travel agents use technology for customers as often as is needed.

B38 To the extent possible, our travel agents use technology in customer service.
.709

.703

.647

.596

.699

.500

.546

.625

.688

.827

.563

.398

\section{.805}

.489

.608

.839

.586

.593

.577

.571

.833

.806

.739

.691

.683

.865

.833

.653

.683

.481 
(Table 2 Continued)

\begin{tabular}{l|l}
\hline Customer retention & .729 \\
\hline B55 Our travel agency systematically attempts to manage the expectations of high-value customers. & .755 \\
\hline B49 Our travel agency maintains interactive two-way communication with our customers. & .624 \\
\hline B36 Our travel agency builds long-term relationships with our high-value customers. & .530 \\
\hline $\begin{array}{l}\text { B20 Our travel agency integrates customer information across customer contact points (e.g. mail, } \\
\text { telephone, Web, fax, face-to-face). }\end{array}$ & .492 \\
\hline B51 Our travel agency actively stresses customer loyalty or retention programmes. & \\
\hline
\end{tabular}

After having established validity and reliability of the construct measurements, further analysis was conducted with the resultant effect being the empirical model depicted in Figure 2.

Figure 2. Final empirical model

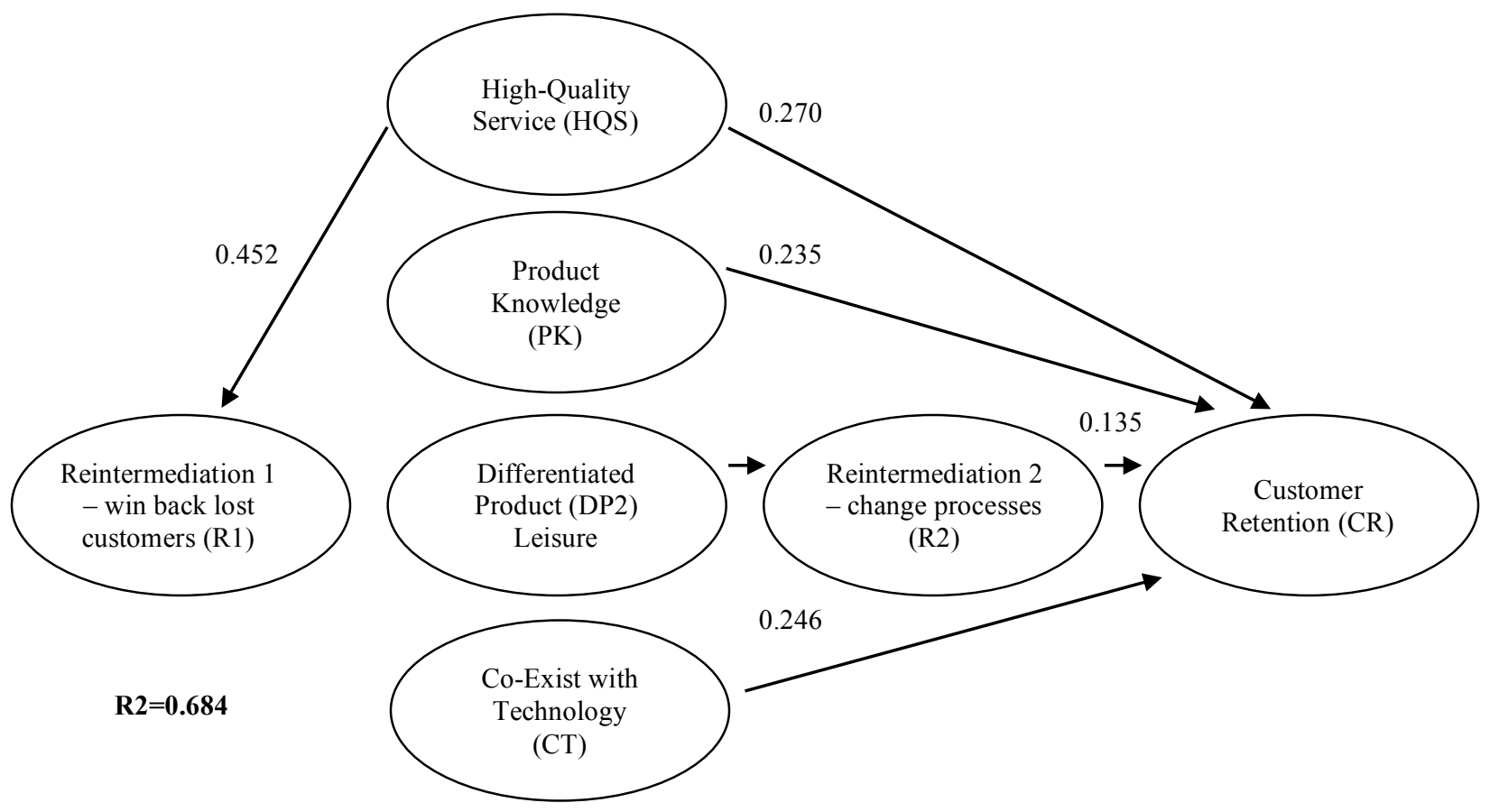

Source: Developed for this study

After having mapped out the empirical model via path analysis, the levels of significance for each relationship between variables needs to be measured. This is evidenced in the form of path coefficients and p-values, as indicated in Figure 2 and Table 3.

Table 3. Summary of the seven significant relationships in the empirical model

\begin{tabular}{|c|c|c|c|}
\hline No. & $\begin{aligned} \text { Factor (strongest to weakest coefficients) } \\
\end{aligned}$ & Path coefficients & $\mathbf{P}$ - values \\
\hline 1 & Reintermediation 1: high-quality service & .452 & .022 \\
\hline 2 & Reintermediation 2: differentiated product (leisure) & .345 & .001 \\
\hline 3 & Reintermediation 1: differentiated product (leisure) & .324 & .000 \\
\hline 4 & Customer retention: high-quality service & .270 & .010 \\
\hline 5 & Customer retention: co-exist with technology & .245 & .000 \\
\hline 6 & Customer retention: product knowledge & .235 & .016 \\
\hline 7 & Customer retention: reintermediation 2 & .135 & .013 \\
\hline
\end{tabular}

The model was tested in its entirety with fit statistics. Table 4 shows the various results regarding the overall fit of the model. 
Table 4. Fit statistics for the Empirical Model

\begin{tabular}{l|c}
\hline \multicolumn{1}{c}{ Index } & Result \\
\hline Bentler-Bonett normed fit index (NFI) & 0.949 \\
\hline Comparative fit index (CFI) & 0.946 \\
\hline Bollen's (IFI) fit index & 0.950 \\
\hline Root-mean-square residual (RMR) & 0.020 \\
\hline Standardised RMR (SRMR) & 0.034 \\
\hline
\end{tabular}

Following the fit statistics is a discussion on the rejection and acceptance of the hypotheses.

\section{Accepting or Rejecting the Formulated Hypotheses}

As per Figure 2 and Table 3, acceptance of the null hypotheses for 1a, 2a, 2b, 3b and 5a took place whilst the alternate hypotheses for $1 \mathrm{~b}, 3 \mathrm{a}, 4 \mathrm{a}, 4 \mathrm{~b}, 5 \mathrm{~b}$ and 6 were accepted. These findings translate into the following results: High-quality service, product knowledge and co-existing with technology are essential in terms of customer retention for travel agencies. Whereas differentiated product (leisure) and high-quality service are necessary for travel agencies to reintermediate their businesses.

High-quality service specifically refers to reintermediating the business by winning back lost customers, and differentiated product (leisure) refers to adapting business processes to reintermediate businesses and retain customers. High-quality service is a strong overriding factor that influences both Reintermediation 1 (winning back lost customers) and customer retention. High-quality service can, therefore, be seen to be an important solution to winning back lost customers and ultimately retaining customers. The results also point out that co-existing with technology and product knowledge has no significant relationships with either of the Reintermediation constructs. Differentiated product (leisure) has a significant relationship with Reintermediation 1, and in turn Reintermediation 2 has a significant relationship with customer retention. In addition to this, the empirical model indicates that Reintermediation 2, specifically modifying business processes to adapt to changing customer needs, is considered important to retain customers in the modern economy. Management implications and recommendations regarding the findings are adopted in the following section.

\section{CONCLUSIVE FINDINGS AND MANAGEMENT RECOMMENDATIONS}

A summary of the findings indicates that the factor that provided the most significant path relationships was that of high-quality service, which proves to have a strong relationship with Reintermediation 1 and customer retention. Differentiated product (leisure) proved to be the second most important factor of importance to travel agency owners/managers in terms of reintermediating their businesses, as it had significant relationships to Reintermediation 1 and Reintermediation 2. The other independent factors in the model each had at least one significant relationship with each of the dependent variables. For example, co-exist with technology has a relationship with customer retention, and product knowledge also has a relationship with customer retention. Finally, there is a significant relationship between Reintermediation 2 and customer retention, which is of the utmost importance as it creates a causal connection and assists in meeting the objectives of the study conducted.

The results of the study reveal that travel agency owners and managers believe that providing differentiated products to their leisure customers is the key to winning back lost customers as well as keeping existing customers. Agency owners and managers indicated that this is an existing reintermediation strategy and an important strategy they plan to practise in the future too. Furthermore, the results indicate that travel agents believe that delivering high-quality service is important to win back lost customers and thus reintermediate their businesses.

Co-existing with technology is revealed to be an important customer retention factor and travel agents are currently using technology as a tool to change the way in which they conduct their business practices to retain customers. Figure 2 indicates that travel agents' knowledge regarding travel products and services has no significant influence on the agent's ability to reintermediate their respective travel agencies, but has a direct influence on customer retention. The final relationship of significance that should be noted is the one that exists between customer retention and Reintermediation 2 (changing business processes). This final result indicated that travel agencies need 
to change business processes to reintermediate their businesses and retain customers in the long term. Personal interaction between customer and agent in the travel industry has no significant influence on the agent's ability to reintermediate their respective travel agencies, and does not appear in the empirical model.

In line with the findings, the recommendations are provided in an order ranging from the most important customer retention/reintermediation factor to the factor of least importance.

\section{Differentiated Product (Leisure)}

With respect to the first set of recommendations which relate to differentiated product, it should be noted that the variable relates solely to the leisure market segment. Therefore, all recommendations made in this regard are relative to leisure customers. The core recommendation to be made with reference to differentiated product relates to travel agencies needing to differentiate holiday products to attract leisure customers. Traditional holiday products and services, such as a local South African trip to Sun City in Gauteng or a vacation to Mauritius, can be booked as easily online as with a travel agent. Also, when the customer books these types of standard holidays online, there is no need for them to pay a service fee as they have to do with a travel agent.

Furthermore, travel agents should also be creating 'dynamically packaged' holidays that customers cannot buy online. Travel agents need to source flight specials, accommodation deals and sightseeing packages for different destinations and package them to create a unique travel product as opposed to relying on tour operators to carry out this function. Different, exotic locations are where to travellers of today are seeking to travel. For example, touring the war tunnels in Vietnam to experience the history in Vietnam, or touring monasteries in Nepal on a spiritual journey. This recommendation suggests that travel agencies should reconsider the traditional distribution channel sales approach of selling packages and travel products from tour operators. The majority of tour operators now sell their products directly to the public, hence negating the need for a travel agent. By travel agents introducing and packaging travel products or tours, they will no longer need to use tour operators as such, and instead will be directly competing with tour operators.

Finally, differentiated leisure products should also be customised, value-added and unique to attract discerning leisure travellers to travel agents and away from online booking sites. Travel agents should also consider customising tour packages for travellers. In addition to focusing on niche market segments with differentiated products, travel agents should consider building customised travel packages for customers. This means tailoring a vacation specifically according to what a customer requires, including making all flight arrangements, hotel bookings, sightseeing excursions, vehicle hire and other transfers required, as opposed to relying on pre-packaged standardised tours. This type of customised package would obviously be most suited to the discerning traveller who is prepared to spend more money, as a complicated travel itinerary does require extensive time and effort on the part of the travel agent. Therefore, it will be necessary to charge higher service fees on these types of services.

\section{High-Quality Service}

As has been established, the provision of high-quality service is important for travel agents in South Africa to reintermediate their businesses and retain customers. Results indicated that high-quality service is the second most important reintermediation factor for travel agents to use to reintermediate their businesses and to retain customers. The three most important recommendations about high-quality service include that the provision of high-quality service cannot be considered a choice for travel agents in South Africa, but a necessity. Any hint of inferior service levels received by customers will result in a distrust of travel agents' services and competencies, leading eventually to a loss of customers. Travel agencies, therefore, need to consistently provide high service levels to keep loyal customers. Also, travel agents need to do more to ensure that their service levels are of an excellent high standard. Monthly customer satisfaction surveys should be conducted as well as biannual mystery shopper exercises with respect to both corporate and leisure travel requests. Customer satisfaction surveys should also cover all of the relevant service quality aspects such as levels of reliability, responsiveness, empathy, assurance and tangibles. Individual travel consultants in agencies should be tested on these various service aspects to ensure that the overall service levels delivered by the agency, are consistent. It is recommended surveys be conducted with corporate customers as well as leisure customers. 


\section{Co-Exist with Technology}

The recommendation indicated in this section is related to the co-existence with the technology construct, which is the third most important customer retention/reintermediation factor for travel agents to use to reintermediate their businesses. If travel agencies are to reintermediate themselves and remain sustainable by retaining customers, they can no longer operate in the same way that they have been doing for the last few decades. The Internet has changed the travel landscape and travel agents need to adapt urgently. The following four recommendations can be made to travel agency managers, namely that travel agents move away from GDS technology and begin to harness online booking technologies. Outdated GDS systems, as well as the IATA structure and associated BSP system, which include expensive guarantees for ticket purchases as well as stringent financial criteria, are expensive liabilities for brick and mortar travel agents. These comprise liabilities that travel cybermediaries and online booking engines do not encounter. In line with the above recommendation, without GDSs, travel agents will need to develop expert skills regarding online booking channels. Their skills need to be far superior to those of the average traveller. Hence the traveller will opt to pay the travel agent to navigate the Internet for travel deals as opposed to doing it themselves. Travel agents should be able to navigate the Internet expertly to create differentiated or customised travel offerings.

In addition to this, travel agents will need to develop joint ventures and collaborations with online booking engines to maximise their presence on the Internet. In essence, they cannot be seen just to have a brick and mortar presence but an online presence as well, where customers can opt to book online with their preferred travel agency if they so wish. Further to this, travel agents who create differentiated products for leisure travellers should use the Internet to promote these products to attract a larger customer base than just their traditional type of customer. Travel agents offering specialised and customised travel packages need to sell their packages online, as this will then enable them to draw customers from all over the world. This opens up and expands their target market which will lead to increased revenue. In effect, the traditional travel agent thus becomes an international tour operator.

\section{CONCLUSION}

The purpose of the study was to develop a model to assist travel agents in South Africa in retaining customers within a disintermediation/reintermediation context. It is evident from the discussion that for travel agency owners/managers to retain customers, it is important that they focus on three specific factors. These factors are delivering continuous high-quality service, continuously maintaining a high level of product knowledge and finally, co-existing with technology to a large degree. It is essential that travel agents attempt to retain customers through these factors and even make attempts to ensure that these factors work in unison to retain customers, for example, differentiating products and delivering a high quality service through the use of technology. Further to this, additional research should be undertaken specifically regarding these three factors and how they can be harnessed to assist travel agents in retaining customers and thus remaining relevant in this modern age.

\section{AUTHOR BIOGRAPHIES}

Kim Viljoen is a Doctoral graduate from the Department of Marketing Management at the University of Johannesburg and a Senior lecturer in the Department of Business Management at the University of Fort Hare in South Africa. She has an interest in the fields of services marketing, social media marketing and relationship marketing and lectures at both undergraduate and post graduate level.

Mornay Roberts-Lombard is a Full Professor of Marketing in the Department of Marketing Management at the University of Johannesburg in South Africa. His areas of specialisation are Relationship Marketing and Customer Management (CRM). He has published articles in both international and South African journals and has delivered conference papers at international and South African conferences. He has been invited as guest speaker at various marketing forums in South Africa. 


\section{REFERENCES}

ABTA Travel Association. (2012). Travel trends report for 2012. Retrieved from www.abta. com / resources.

Ahmad, R., \& Buttle, F. (2002). Customer retention management: a reflection of theory and practice. Marketing Intelligence and Planning, 20(3), 149-161.

Andreu, L., Aldas, J., Bigne, A. \& Mattila, S. (2010). An analysis of e-business adoption and its impact on relational quality in travel agency-supplier relationship. Tourism Management, 31, 777-787.

Bove, L.L., \& Johnson, L.W. (2009). Does 'true' personal or service loyalty last? A longitudinal study. Journal of Services Marketing, 23(3), 187-194.

Buttle, F. (2009). Customer relationship management: Concepts and technologies (2nd edn). London: Elsevier. Cant, M.C., Strydom, J.W., Jooste, C.J., \& du Plessis. (2006). Marketing Management. (5th edn.). Cape Town: Juta.

Chau, P.Y.K., \& Hu, P.J. (2001). Information Technology Acceptance by Individual Professionals: A Model Comparison Approach. Decision Sciences, 32 (4), 707.

Cheung, W. (2012). Trends in travel industry. Retrieved from http://hdl.handle.net/10214/3696.

Dolnicar, S., \& Laesser, C. (2007). Travel agency marketing strategy: Insights from Switzerland. Journal of Vacation Marketing, 46, 133-146.

European Travel Commission. (2007). New Media Review. Retrieved from Error! Hyperlink reference not valid.. Ferrell, O.C., \& Hartline, M.D. (2008). Marketing Strategy. (4th edn.). Australia: Thomson.

Frost, E., Nordlof, J., \& Svesson, M. (2009). Relationship marketing in the travel industry. Retrieved from http:hj.se. Garkavenko, V. (2007). New Zealand travel agents in the internet era: impacts, responses and relationships. Doctor of Philosophy Thesis, Auckland University of Technology, New Zealand.

Gaynor, W. (2006). Technology is the key to growth in 2006. Travel Industry Review, January, pp 811. George, R. (2008). Marketing Tourism in South Africa. (4th edn.). Cape Town: Oxford.

Gerber, J. (2006). It's only a matter of time before underhanded agents are caught. Travel Industry Review, January, p.11.

Grisseman, U. S., \& Stokburger-Sauer, N.E. (2012). Customer co-creation of travel services: The role of company support and customer satisfaction with the co-creation performance. Tourism Management, 33, 1483-1492.

Gustafsson, A., Johnson, M.D., \& Roos, I. (2005). The Effects of Customer Satisfaction, Relationship Commitment dimensions, and triggers on Customer Retention. Journal of Marketing, 69, 210.

Hanson, W., \& Kalyanam, K. (2007). Internet Marketing and e-Commerce. Australia: Thomson.

Huang, L., Chen, K., \& Wu, Y. (2009). What kind of marketing distribution mix can maximize revenues: The wholesaler travel agencies 'perspective? Tourism Management, 30, 733-739.

Huang, L., Yung, C.Y., \& Yang, E. (2011). How do travel agencies obtain a competitive advantage? Through a travel blog marketing channel. Journal of Vacation Marketing, 17(2), 139-149.

Kracht, J., \& Wang, Y. (2009). Examining the tourism distribution channel: evolution and transformation. International Journal of Contemporary Hospitality Management, 2(22), 736-757.

Kruger-Cloete, E. (2007). National Research and Technology Foresight Project - National Advisory Council on Innovation.

Retrieved from http://www.naci.org.za.

Ku, E. C. S., Yang, C., \& Huang, M. (2012). Partner choice: Adaptation of strategic collaboration between travel agencies.

Journal of Hospitality and Tourism Research. Retrieved from http://sagepublications.com.

Lloyd, A.E., \& Luk, S.T.K. (2011). Interaction behaviours leading to comfort in the service encounter. Journal of Services Marketing, 25(3), 176-189.

Lubbe, B.A., Endres, B., \& Ferreira, J. (2006). Leisure travellers' willingness to pay travel agents in a new revenue environment: A survey based in South Africa. Southern African Business Review, 10(1), 35-50.

Nitzan, I., \& Libai, B. (2011). Social Effects on Customer Retention. Journal of Marketing. 75, 24.

O'Bearden, W.O., \& Netermeyer, R.G. (1999). Handbook of Marketing Scales: Multi-Item Measures for Marketing and Consumer Behavior Research. 2nd edn. London: Sage. pp. 101-290.

Parasuraman, A., Zeithaml, V.A., \& Berry, L.L. (1998). SERVQUAL: A Multiple-Item Scale for Measuring Consumer Perceptions of Service Quality. Journal of Retailing, 64(1), 39.

Ple, L., \& Caceres, R.C. (2010). Not always co-creation: introducing interactional Co-destruction of value in servicedominant logic. Journal of Services Marketing, 24(6).

Reinartz, W., Krafft, M., \& Hoyer, W.D. (2004). The Customer Relationship Management Process: Its Measurement and Impact on Performance. Journal of Marketing Research, 41(3),303.

Rutter, R. (2006). The challenge for 2006 is to maintain profitable structures. Travel Industry Review, January, pp210. Salvado, J.O.M., Ferreira, A.M.A., \& Costa, C.M.M. (2011). Co-creation: the travel agencies new frontier. International

Conference on Tourism and Management Studies, 1, 229-244. 
Schulze, C., Skiera, B., \& Wiesel, T. (2012). Linking Customer and Financial Metrics to Shareholder Value: The Leverage Effect in Customer- Based Valuation. Journal of Marketing, 76,17.

Shaw, S. (2007). Airline Marketing and Management. (6th edn.). Hampshire: Ashgate.

Shunk, D.L., Carter, J.R., Hovis, J., \& Talwar, A. (2007). Electronics industry drivers of intermediation and disintermediation. International Journal of Physical Distribution and Logistics Management, 37(3), $248-261$.

Spake, D.F., \& Megehee, C.M. (2010). Consumer sociability and service provider expertise influence on service relationship success. Journal of Services Marketing, 24(4).

Spielmann, N., \& Babin, B.J. (2011). Service with personality: a note on generalizing personality across services contexts. Journal of Services Marketing, 25(7).

Thomson, N. (2008). ASATA goes international with WTAAA. Travel News Weekly, 30 April. p.2.

Ting. Y. (2012). E-newsletter as a marketing tool for hospitality and travel firms to retain customers. African Journal of Business Management, 6(12), 4551-4558.

Trassorras, R., Weinstein, A., \& Abratt, R. (2009). Value, satisfaction, loyalty and retention in professional services. Marketing Intelligence and Planning, 27(5), 615-632.

Trivedi, M., Morgan, M.S., \& Desai, K.K. (2008). Consumer's value for informational role of agent in service industry. Journal of Services Marketing, 22(2), 149-159.

Turen, R. (2008). Finding niche gold in a world of tarnished silver. Retrieved from http://www.travelweekly.com.

Verbeke, W., Dietz, B., \& Verwaal, E. (2010). Drivers of Sales Performance: a contemporary meta-analysis, have salespeople become knowledge brokers? Journal of the Academy of Marketing Science, 39(1), 407-428.

Viljoen, K., Roberts-Lombard, M. \& Jooste, C.J. (2015) Reintermediation Strategies for Disintermediated Travel Agencies: A strategic marketing perspective. International Business and Economics Research Journal, 14(3), 561-574.

Voss, G.B., \& Voss, Z.G. (2008). Competitive Density and the Customer Acquisition-Retention Trade-Off. Journal ofMarketing, 72, 3-18.

Wang, T., Gal-Or, E., \& Chatterjee, R. (2009). The name-your-own-price channel in the travel industry: An analyticalexploration. Management Science, 55(6), 968-979.

Wardall, J. (2006) (b). Low-cost revolution sees agency sales drop. Travel Industry Review, June. p.24.

Wolfe, K., Kang, S., \& Hsu, C. (2005). Identifying travel agent user segments. Journal of Hospitality and Leisure Marketing, 12(4), 72-92.

World Travel Market. (2010). World Travel Market 2010 Industry Report. Retrieved from http://etccorporate.org/resources. World Travel Trends Report. (2011/2012). Travel Industry know how. Retrieved from http.itb-berlin.com/library. 